\title{
Perbaikan Sistem Kerja Pada Industri Rumah Tangga Sepatu Di Cibaduyut Bandung Untuk Meminimasi Beban Kerja Mental \\ ${ }^{1}$ Nur Rahman As'ad, ${ }^{2}$ Eri Achiraeniwati, ${ }^{3}$ Yanti Sri Rejeki \\ ${ }^{1,2,3}$ Fakultas Teknik, Universitas Islam Bandung \\ email: ${ }^{1}$ nur_asad@yahoo.com, ${ }^{2}$ eri_ach@yahoo.co.id, ${ }^{3}$ ysrejeki@yahoo.com
}

\begin{abstract}
Abstrak. Standarisasi sistem kerja sangat diperlukan baik utuk perusahaan maupun untuk pekerja, standarisasi memudahkan bagi perusahaan dalam membuat perencanaan dan target perusahaan. Bagi pekerja standarisasi merupakan panduan dalam memudahkan pekerja melakukan pekerjaannya. Penelitian ini (tahun ke-dua) bertujuan mengintegrasikan hasil penelitian yang dilakukan dari tahun 2012 - 2014 serta diuji cobakan, sehingga menghasilkan standarisasi sistem kerja pada industri sepatu di Cibaduyut yang meliputi spesifikasi dan bentuk fisik fasilitas yang digunakan, metoda kerja untuk setiap stasiun kerja serta lingkungan fisik kerja yang memenuhi syarat pekerjaannya. Dengan standarisasi sistem kerja diharapkan pekerja lebih nyaman dan aman dalam melakukan pekerjaaannya dan membantu dalam pencapaian target.
\end{abstract}

Kata kunci : Standarisasi, Sistem kerja, Nyaman, Aman

\section{Pendahuluan}

Proses produksi alas kaki Cibaduyut terdiri dari proses pemolaan, penjahitan, pemasangan sol dan proses finishing. Semua proses tersebut dilakukan secara manual dengan fasilitas kerja yang tidak ergonomis, tanpa ada panduan metode kerja yang ditetapkan/baku serta lingkungan kerja yang tidak memenuhi persyaratan. Kondisi tersebut mengakibatkan sistem kerja tidak ergonomis, yang akan mengakibatkan resiko terhadap aspek kenyamanan, keselamatan dan kesehatan kerja serta berakibat pada pencapaian produktivitas kerja. Sistem kerja yang ergonomis memperhatikan lima aspek yaitu, pekerja, material, mesin yang digunakan, metoda kerja serta dukungan lingkungan fisik kerja yang memenuhi syarat. Hasil identifikasi dari kelima aspek tersebut berupa standarisasi sistem kerja untuk objek yang diamati, sehingga diharapkan pencapaian produktivitas dapat tercapai dengan aman, nyaman dan sehat. Pada penelitian As'ad (2013) telah dilakukan perbaikan metode kerja dan pembuatan fasilitas kerja dengan mempertimbangkan aspek-aspek ergonomis dalam proses perancangannya, dengan tujuan untuk meminimasi resiko kerja terhadap segmen anggota tubuh pekerja serta diharapkan pekerja merasa nyaman dengan fasilitas tersebut sehingga berdampak pada peningkatan produktivitas kerja. Pencapaian tujuan di atas memerlukan proses adaptasi pengrajin dalam menerapkan metode kerja dan penggunaan fasilitas kerja hasil rancangan tersebut. Proses tersebut membutuhkan usaha yang besar, karena disamping beradaptasi dengan sistem kerja dan fasilitas kerja yang baru para pengrajin harus memenuhi target produksi yang telah ditetapkan. Hal ini memungkinkan pengrajin akan mengalami beban mental yang tinggi. Beban mental yang tinggi mengakibatkan menurunnya performance kerja yang akan berimbas pada 
menurunnya produktivitas perusahaan. Selain itu beban mental dipengaruhi juga oleh kondisi lingkungan kerja. Oleh karena itu diperlukan pengkajian terhadap beban mental dan lingkungan kerja tersebut. Hasil dari penelitian tersebut kemudian di implentasi dan evaluasi, yang selanjutnya dibuat standarisasi kerja.

\section{Kajian Literatur}

Sutalaksana (2006) mendefinisikan Perancangan Sistem Kerja adalah suatu ilmu yang terdiri dari teknik-teknik dan prinsip-prinsip untuk mendapatkan rancangan terbaik dari sistem kerja yang bersangkutan. Teknik-teknik dan prinsip-prinsip digunakan untuk mengatur komponen sistem kerja yang terdiri dari manusia, dengan sifat dan kemampuannya, peralatan kerja, bahan serta lingkungan kerja sedemikian rupa sehingga dicapai efektivitas dan efisiensi yang tinggi bagi perusahaan serta aman, sehat dan nyaman.

Pengukuran kebaikan rancangan sistem kerja dilakukan berdasarkan waktu yang dihabiskan untuk bekerja, beban-beban fisik yang dialami serta akibat-akibat psikologis dan sosiologis yang ditimbulkan bahkan terhadap biaya.

Sistem kerja terdiri dari empat komponen, yaitu manusia, bahan, perlengkapan, dan peralatan serta lingkungan kerja. Elemen-elemen tersebut yang mempengaruhi efisiensi dan produktivitas kerja. Beberapa penelitian yang berkaitan dengan system kerja tersebut adalah sebagai berikut:

- Penelitian Tri Wulandari dkk. (2008), mengenai Identifikasi Resiko Ergonomi pada Pekerja dengan pekerjaan manual menunjukan hasil pada stasiun kerja gerinda bekerja kurang nyaman yang disebabkan posisi kerja operator yang kurang nyaman dan fasilitas kerja yang kurang memadai dan tidak ergonomis sehingga menimbulkan metode kerja yang kurang baik.

- Penelitian Sri Rejeki, dkk. (2010) mengenai Perbaikan Fasilitas Kerja dengan pendekatan Ergonomi pada pekerjaan manual di bagian pembuatan sol sepatu menunjukan hasil bahwa pekerja merasakan keluhan pada beberapa segmen tubuhnya yang disebabkan karena fasilitas kerja yang tidak ergonomis sehingga melakukan gerakan kerja atau metoda kerja yang tidak tepat.

- Penelitian yang dilakukan Jiang (2004) mengenai Perbaikan Sistem Kerja bagian packing menghasilkan waktu baku yang lebih singkat.

- Penelitian As'ad dkk (2012 \& 2013) mengenai perbaikan sistem kerja dengan pendekatan ergonomi pada industri sepatu Cibaduyut menghasilkan implementasi dan evaluasi fasilitas kerja serta rancangan metode kerja untuk setiap stasiun kerja.

- Penelitian As'ad (2014) mengenai perbaikan sistem kerja pada industri sepatu Cibaduyut untuk meminimasi beban kerja mental menghasilkan rancangan sistem kerja.

\section{Metode Penelitian}

Pengumpulan data dilakukan dengan penyebaran kuesioner, wawancara dan studi lapangan, dengan jumlah sampel sebanyak sembilan home industry di Cibaduyut. Data yang dikumpulkan pada penelitian ini adalah data beban kerja mental yang didapat dengan menyebarkan kuesioner NASA-TLX, Lingkungan fisik kerja, metode kerja, dan 
fasilitas kerja. Data lingkungan kerja diperoleh dengan cara mengukur langsung kondisi lingkungan, yaitu suhu, kelembaban, pencahayaan, kebisingan, bau-bauan, dan warna. Alat yang digunakan adalah Hygrometer, Barometer, Lux meter, Sound level meter. Data metode dan fasilitas kerja diperoleh dari hasil penelitian yang dilakukan pada tahun 2012 dan 2013. Selanjutnya dibuat rancangan sistem kerja dengan memperhatikan faktor-faktor lingkungan kerja, metode kerja, dan fasilitas kerja. Hasil rancangan yang dibuat diimplementasikan untuk dilakukan uji coba, kemudian dilakukan evaluasi. Setelah rancangan yang dibuat sesuai dengan tujuan, maka sistem kerja tersebut ditetapkan sebagai standar sistem kerja yang dapat diterapkan pada seluruh industri rumah tangga sepatu yang ada di Cibaduyut.

\section{Hasil dan Pembahasan}

Penelitian ini merupakan kelanjutan dari penelitian tahun sebelumnya (2014), yang menghasilkan rancangan sistem kerja untuk meminimasi beban kerja mental. Hasil akhir yang ingin dicapai dari penelitan ini adalah penetapan standar kerja untuk home industry sepatu. Oleh karena itu aktivitas yang dilakukan pada penelitian ini adalah implementasi dan evaluasi dari rancangan yang dihasilkan pada penelitian tahun 2014, dan penetapan standar sistem kerja. Aktivitas-aktivitas tersebut belum semua terlaksana. Aktivitas yang sudah terlaksana sampai dengan saat ini adalah implementasi rancangan. Adapun aktivitas yang dilakukan pada implementasi rancangan ini adalah sebagai berikut:

1. Pembuatan fasilitas kerja

Fasilitas kerja yang dirasakan belum nyaman oleh pekerja adalah fasilitas kerja pada stasiun kerja pola dan sol. Oleh karena itu dibuat rancangan perbaikan pada fasilitas tersebut dan direalisasikan pada tahun ini. Fasilitas kerja untuk stasiun pola dan sol sebelum rancangan dapat dilihat pada Gambar 1 dan 2, sedangkan stasiun kerja pola dan sol setelah hasil perbaikan dapat dilihat pada Gambar 3 dan 4.
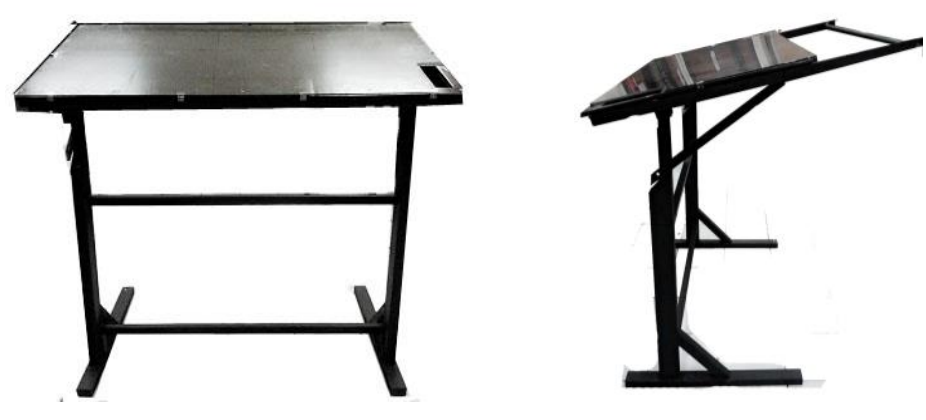

Gambar 1 Meja Pola sebelum perbaikan 
314 | Nur Rahman As'ad, et al.
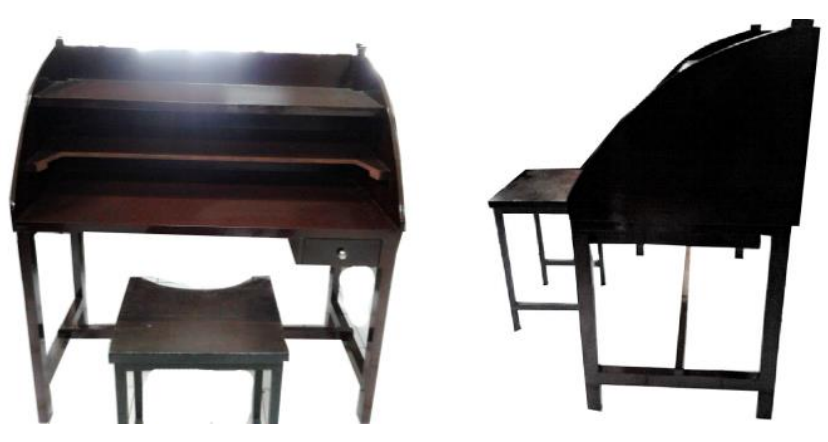

Gambar 2 Meja Sol sebelum perbaikan

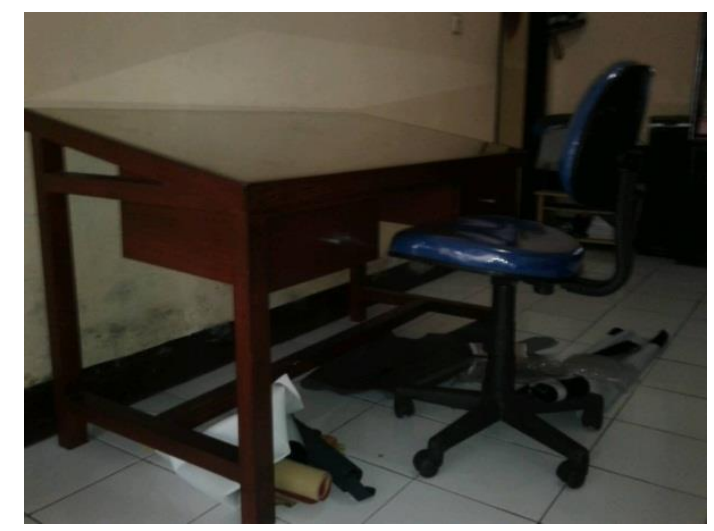

Gambar 3 Meja Pola setelah perbaikan

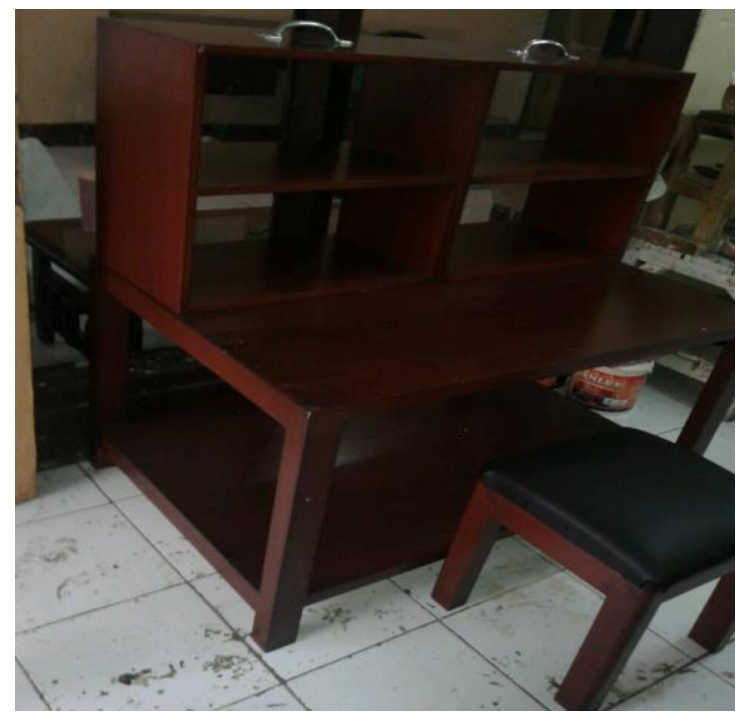

Gambar 4 Meja Sol setelah perbaikan 
2. Pengadaan mesin press

Tujuan dari pengadaan mesin press adalah untuk mengurangi beban kerja pada stasiun kerja sol. Aktivitas pemasangan sole merupakan kegiatan pemasangan komponen atas yang dihasilkan oleh bagian penjahitan yang digabungkan dengan beberapa komponen sehingga menjadi produk sepatu. Kegiatan penggabungan bagian atas dengan alas sepatu dilakukan dengan cara direkatkan dengan lem dan dipukul-pukul menggunakan palu supaya lem merekat dengan kuat. Perekatan lem tersebut dilakukan d atas kaki bagian atas pekerja. Hal ini sangat beresiko terhadap kesehatan pekerja. Oleh karena itu, dengan pengadaan mesin press aktivitas perekatan tersebut dilakukan oleh mesin press. Gambar mesin press dapat dilihat pada Gambar 5.

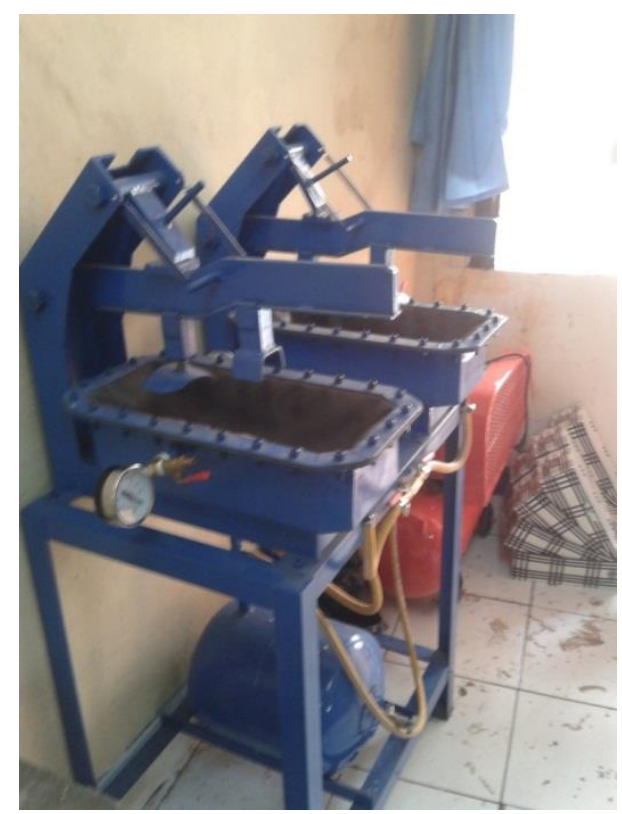

Gambar 5 Mesin Press

3. Perbaikan lingkungan fisik kerja

Lingkungan fisik kerja merupakan salah satu faktor penting dalam suatu sistem kerja. hasil pengukuran lingkungan fisik kerja yang dilakukan pada penelitian As'ad (2014) menunjukkan bahwa perlu adaanya perbaikan lingkungan fisik kerja. Oleh karena itu dilakukan perbaikan dengan membuat ventilasi udara, pengecatan, pemasangan lampu untuk tingkat pencahayaan yang direkomendasikan (Gambar 6), dan pemasangan kipas angina (Gambar 7). 


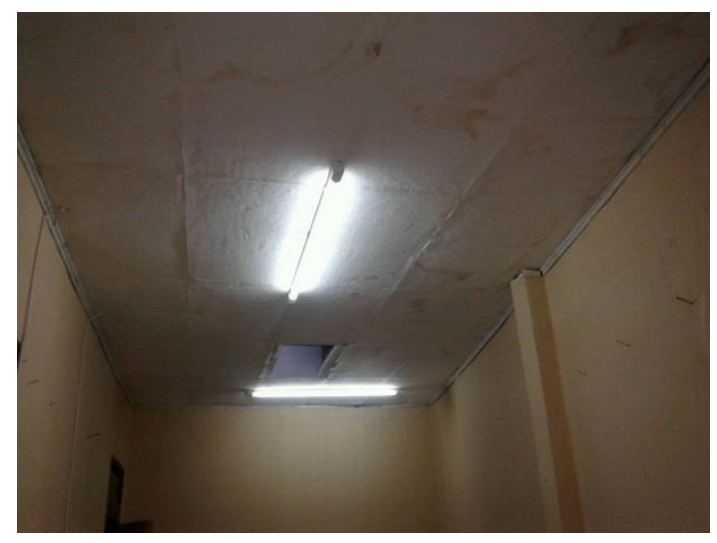

\section{Gambar 6. Pembuatan ventilasi dan pemasangan lampu}

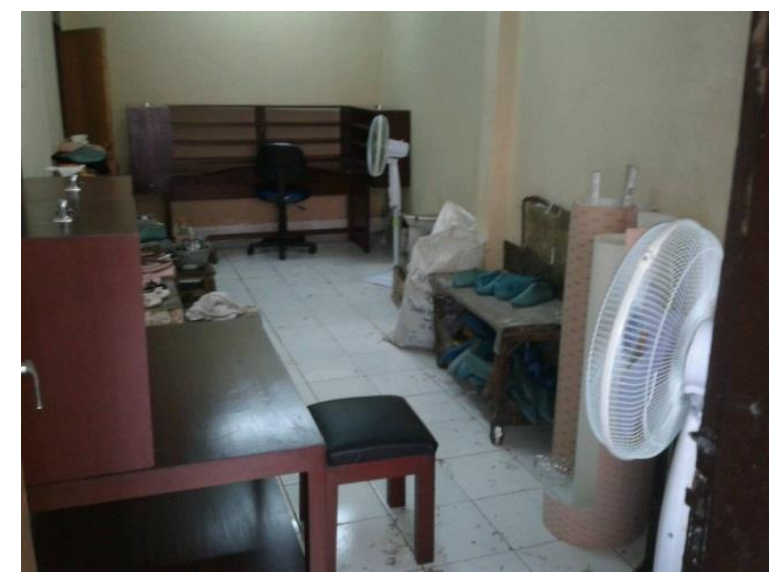

Gambar 7. Pemasangan Kipas Angin

\section{Kesimpulan}

Kesimpulan dari penelitian yang telah dilakukan adalah sebagai berikut:

1. Aktivitas yang telah dilakukan adalah pembuatan fasilitas kerja yang telah diperbaiki sesuai dengan rancangan dengan memperhatikan prinsip-prinsip ergonomi.

2. Fasilitas kerja yang dibuat adalah meja kerja pola, sol, dan finishing.

3. Mesin Press disediakan untuk mengurangi beban kerja pada stasiun kerja sol.

4. Perbaikan lingkungan fisik kerja dilakukan dengan pembuatan ventilasi udara, pemasangan lampu dengan tingkat penerangan yang disesuaikan, pemasangan kipas angin, dan pengecatan ruangan.

Adapun saran dari hasil penelitian adalah sebagai berikut :

1. Perusahaan atau home industry sebaiknya lebih memperhatikan kondisi pekerja dengan melihat fasilitas-fasilitas kerja yang dipakai agar pekerja dapat bekerja lebih baik dan tidak memberikan dampak yang buruk bagi pekerja.

2. Saran untuk penelitian selanjutnya adalah penelitian budaya kerja pekerja dalam membiasakan diri terhadap fasilitas dan metode kerja yang baru. 


\section{Daftar Pustaka}

Arief, Latar M., 2012. Lingkungan Kerja Faktor Debu http://ikk354.blog.esaunggul.ac.id[ diakses 01 Desember 2013].

As'ad, Nur Rahman, Achiraeniwati, Sri Rejeki, 2012, Usulan Perbaikan Metode Kerja Pada Stasiun Kerja Pola Dengan Motion Economy Checklist (Studi Kasus Industri Rumah Tangga Sepatu Cibaduyut "X"), Seminar Nasional Penelitian dan Pengabdian Masyarakat (SNaPP), 13 November 2012, ISSN 2089-3590

Cahyadi, Dwi dan Kurniawan,Andri., 2000. Riset: Pengukuran Lingkungan Fisik Kerja dan Workstation Di Kantor Pos Pusat Samarinda, Vol.7 No.2.

Chengalur, Rodgers and Bernard, 2004, Ergonomic Design for People at Work, John Wiley \& Sons, Inc., Hoboken, New Jersey.

Chapanis Alphonse, 1985, Human Factors in System Engineering, John Wiley, New Jersey

Groover, Mikell P., 2007. Work system and the methods, measurement, and management of work. United states of America: Pearson education, Inc.

Jiang, Tjen, 2004, Usulan perbaikan Sistem Kerja Bagian Packing pada Proses Pembuatan Sweater di PT XYZ, Thesis, Petra Chistian University.

Sutalaksana, Iftikar Z., 2006. Teknik Perancangan System Kerja.Bandung: ITB

Sri Rejeki, Yanti, Eri Achiraeniwati, 2010, Perbaikan Fasilitas Kerja Dengan pendekatan Ergonomi: Studi Kasus Industri Rumah Tangga Sepatu Cibaduyut CV Gerund, Prosiding Nasional Teknik Industri Unisba: Pemberdayaan Rekayasa Industri berbasis Eco-Efficiency pada Era Perdagangan Bebas, 24 November 2010, ISBN 978-602-98058-0-2.

Sri Rejeki, Yanti, As'ad, Achiraeniwati, 2013, Impovement of Work System with Ergonomic Approach on Domestic Shoes Industry in Cibaduyut Bandung, Conference $1^{\text {St }}$ International Materia, Industrial Manufacturing and Engineering Conference (MIMEC), Johar Baru Malaysia.

Sri Rejeki, Yanti, As'ad, Achiraeniwati, 2014, Perbaikan Sistem Kerja Pada Industri Rumah Tangga sepatu di Cibaduyut untuk Meminimasi Beban kerja Mental, Industrial Engineering Conference IDEC 2014, Teknik Industri UNS Solo.

Triwulandari S. Dewayana, Nora Azmi, Rivana, 2008, Identifikasi Resiko Ergonomi pada Pekerja di PT ASABA Industri, Jurnal J@TI, UNDIP, Mei, Vol III No.2.

Tjen Jiang, 2004, Usulan perbaikan Sistem Kerja Bagian Packing pada Proses Pembuatan Sweater di PT XYZ, Thesis, Petra Chistian University. 